\title{
Analysis of the fragility of the Environmental Protection Area Alto Rio Doce, MG, Brazil
}

\author{
Análise da fragilidade da Área de Proteção Ambiental Alto Rio Doce, MG, Brasil
}

\author{
Carlos Frederico Baumgratz Figueirôa', Geraldo Majela Moraes Salvio ${ }^{\text {II }}$
}

\begin{abstract}
Currently, the Atlantic Forest is one of the most fragmented biomes. The objective of this study was to diagnose the environmental fragility of Alto Rio Doce Environmental Protection Area(EPA) in Minas Gerais, through characterizationof the distribution of local fragmentation, as well as the provision of pressure on vegetation. The vegetation was characterized using a supervised classification of an image captured by the OLI sensor aboard Landsat 8 . Only $22.3 \%$ of the entire extension of the EPA, which contains 23,329 hectares, has vegetation, which is composed of many small fragments. In addition, the EPA is intersected by roads, one being a state paved road, which accelerates habitat fragmentation, causing damage to both animal and plant species. We conclude that in order to achieve its objectives, the area is in need of a management plan, as well as initiatives to educate the general public about the EPA.
\end{abstract}

Keywords: Protected area; Georeferencing; Fragmentation

\section{Resumo}

Atualmente a Mata Atlântica é um dos biomas mais fragmentados. O objetivo deste estudo foi diagnosticar a fragilidade ambiental da Área de Proteção Ambiental (APA) Alto Rio Doce em Minas Gerais, por meio da caracterização da distribuição da fragmentação local, bem como da pressão sobre a vegetação. A caracterização da vegetação foi feita por classificação supervisionada, por meio da imagem captada pelo sensor OLI presente no Landsat 8 . Apenas $22,3 \%$ de toda a extensão da APA, que contém 23.329 hectares, apresenta vegetação, sendo composta por muitos pequenos fragmentos. Além disso, a APA é cortada por estradas, sendo uma delas pavimentada e estadual, o que agrava a situação da fragmentação dos habitats, causando danos tanto a espécies animais quanto vegetais. Concluiu-se que para atingir seus objetivos é preciso a elaboração de um plano de manejo para a área, além de alternativas que permitam a popularização da APA tornando-a mais conhecida pela população local.

Palavras-chave: Área protegida; Georreferenciamento; Fragmentação

Gestor Ambiental, Me., Gestor Ambiental da Prefeitura Municipal de Alto Rio Doce, Av. dos Pereiras, 2315, Bairro Nossa Senhora de Lourdes, CEP 36260-000, Alto Rio Doce (MG), Brasil. baumgratz.figueiroa@hotmail.com (ORCID: 0000-0002-2854-6510)

II Biólogo, Dr., Professor do Núcleo de Ciências Ambientais, Campus Barbacena, Instituto Federal do Sudeste de Minas Gerais, Rua Monsenhor José Augusto, 204, Bairro São José, CEP 36205-018, Barbacena (MG), Brasil. geraldo.majela@ifsudestemg.edu.br (ORCID: 0000-0002-3953-1349) 


\section{Introduction}

The Atlantic Forest biome is known for the richness and diversity of its species, although it has been continually subject to impacts throughout the centuries. Currently the landscape is composed of small islands of vegetation, which are becoming increasingly isolated as a result of intense forest fragmentation (CALEGARI et al., 2010). This scenario likely interferes with the maintenance of biodiversity (KNÖRR; GOTTSBERGER, 2012).

Currently, about $12 \%$ of its original area remains in small, isolated parts, $84 \%$ of which are less than 50 hectares. Although under threat, between 2016 and 2017, 12,562 ha were deforested in the Atlantic Forest, the lowest since 1985. The state of Minas Gerais, which had led the ranking of deforestation since it was created, accounting for half of destruction of the biome from 2010 to 2016 , with a total of 10,752 hectares of the lost biome and increase in deforestation rate of 70\% between 2011 and 2012. Currently, the state occupies second place with 58\% decrease in deforestation rate and maintains a coverage of $11.6 \%$ of the original Atlantic Forest (SOS MATA ATLÂNTICA, 2018).

The creation of Protected Areas (PA) has been encouraged as the most effective way to conserve the forest remnants. PAs represent the chief strategy to conserve nature, protecting species, genetic resources and landscapes of great scenic beauty, as well as guaranteeing areas for scientific research, environmental education, outdoor recreation and ecotourism (BUTCHART et al., 2010). In addition, they promote the rational and sustainable use of natural resources and represent economic development for many municipalities through the direct and indirect use of these areas.

The creation of Protected Areas in states and municipalities allows new agents to become involved in the discussions of the global conservation network, enabling new political, social, cultural and environmental connections (MARTIN et al., 2016). Protected Areas should function as decentralization mechanisms that allow connectivity between federal lands, promoting better land use and cooperation among managers from different spheres of government (FREITAS LIMA; RANIERI, 2018).

Among the various categories of PA in Brazil, the Environmental Protection Area (EPA) is the least restrictive category (SALVIO et al., 2016). EPAs, inspired by the Natural Parks of Portugal, has the central objective of enabling peaceful coexistence between conservation and natural resource use through productive activities. Since 2000, EPAs have proliferated throughout Brazil, chiefly as a means of guaranteeing the implementation of a PA in those municipalities of the states like Minas Gerais where the Ecological ICMS laws have been enacted (OLIVEIRA et al., 2012). The Ecological Goods and Services (or ICMS Ecológico) tax essentially allows municipalities greater access to state funding than those to which they are already entitled if they comply with or exceed certain criteria in state environmental laws. However, the limited restriction of this category of management, leads in a direction of the function of this model to a land use planning, to the detriment of conservation itself.

Despite the low restriction of this category of PA, there are those who see opportunities in them to develop strategies for sustainably managing natural resources (MURADIAN et al., 2010). On the other hand, many consider them ineffective from a conservation point of view. In practice they cite their inability to provide adequate environmental, contributing little more than a buffer zone to other protection categories or to guarantee ecological corridors. In the best of situations, this category would lend itself to the sustainable use of resources and not to the protection of the natural patrimony (SALVIO et al., 2016).

On the land area of Minas Gerais, 9.26\% are formal Protected Areas, of which $69.9 \%$ are Environmental Protection Areas (EPA), that despite their low restriction have a great appeal and, due to this attractive name gives a false impression of conservation (SALVIO, 2017). The Atlantic Forest, one of the most important global biodiversity hotspots, is vulnerable to being "protected" by EPA. Only $1.53 \%$ of the area of Minas Gerais is protected under so-called "Integral Protection" 
regimes (SALVIO et al., 2016). In this way, letting such an important biome protected by this category can compromise its integrity in the medium term.

The environmental fragility is a term used by Ross (1994) that shows the human influence under the popular ecosystem in dynamic balance. Although the genetic characteristics on the area can impact this dynamic, the human intervention can disbalance faster than natural conditions, according to the author. This way, the environmental fragility can be influenced by vegetal coverage, slope, soil type and mainly by land use, such as urbanization, agriculture and livestock.

The objective of this study was to diagnose the environmental fragility of Alto Rio Doce EPA in Minas Gerais, through characterization of the distribution of local fragmentation, as well as the provision of pressure on vegetation.

\section{Material and method}

The Alto Rio Doce Environmental Protection Area is located in the municipality of Alto Rio Doce, Minas Gerais (Figure 1), at $24^{\circ} 00^{\prime} \mathrm{W}$ and $21^{\circ} 04^{\prime} \mathrm{S}$. It has 23,329 hectares, representing $40.15 \%$ of the municipal territory and it borders with the municipalities of Senhora dos Remédios, Desterro do Melo and Mercês. It is in the geomorphological unit Planalto Sul Mineiro / Depressão de Belo Horizonte, with an average altitude of 828 meters. The climate is classified in Tropical of Altitude, or Cwb, according to the classification of Köppen, with average annual temperature of $19.1^{\circ} \mathrm{C}$ and average monthly precipitation of 126 millimeters (ALVARES et al., 2014). The area lies within the morphoclimatic domain of the Atlantic Forest, with vegetation predominantly of Seasonal Semi-deciduous Forest.

\section{Figure 1 - Location of the Alto Rio Doce Environmental Protection Area (EPA) in relation to the Alto Rio Doce municipality in Minas Gerais}

Figura 1 - Localização da Área de Proteção Ambiental (APA) Alto Rio Doce em relação ao município Alto Rio Doce em Minas Gerais

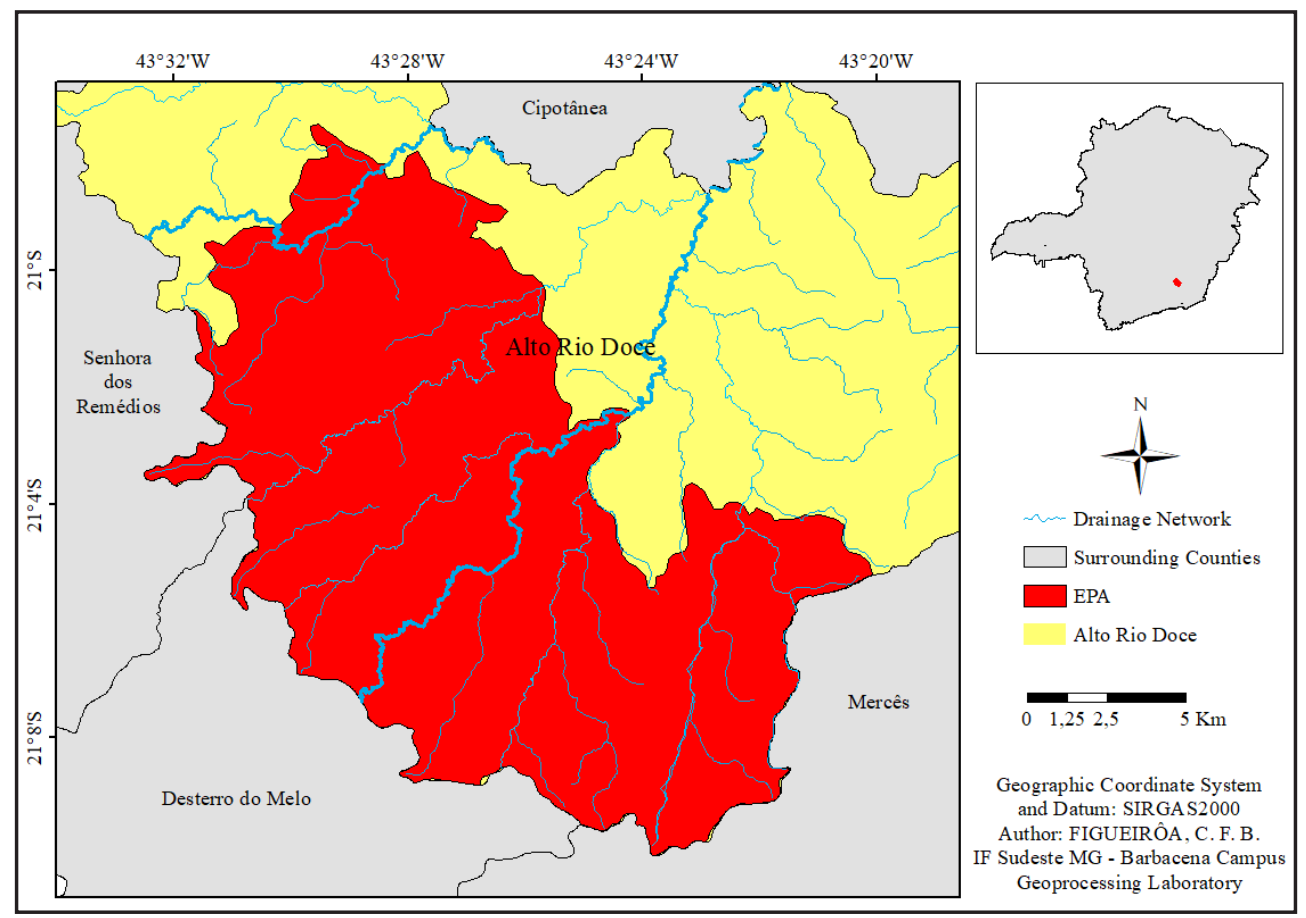

Source: Authors (2020) 
The EPA vegetation was mapped by means of the supervised classification method of satellite imagery, using a Maximum Likelihood classifier in the ArcGIS 10.5.1 software package and for further accuracy analysis for classification was used the kappa coefficient, which varies between 0 (poor) to 1 (very good) (RITTL et al., 2013). The base image was the captured by the OLI sensor on the Landsat 8 satellite platform (Track 217, Row 075, acquired on August 29, 2017) and has a spatial resolution of $30 \mathrm{~m}$. The bands used for this research was the false colors infrared was displayed as 5, 4, 3, commonly applied to show vegetation. Two classes were determined to generate thematic image: non-vegetation and vegetation. The non-vegetation class was designated as all land that has undergone anthrogenic influence, such as urban areas, agriculture and pastureland, while the vegetation class represents all kinds of arboreal vegetation, natural or not. It should be noted that it was beyond the scope of this analysis to distinguish between native and planted vegetation due to a lack of adequate reference information and since the scale of the preserve and made it unfeasible to acquire ground truth data ourselves.

Another factor of relevance to the analysis was the topographic relief of the area, which fits a profile that according to Massa and Ross (2012), may indicate the possibility of erosive processes, landslides and floods, depending on the degree of slope. The hierarchical slope classes used in the study (Table 1) were elaborated by Ross (1994). Topographic slope was mapped by processing the Satellite Shuttle Radar Topography Mission (SRTM) DEM product (FARR et al., 2007) for our study area, which was then downscaled to 15 meters resolution. Subsequently, slope was calculated using the slope tool in the ArcGIS 10.5.1 software.

Table 1 - Hierarchical classification of the slope of the relief developed by Ross, 1994

Tabela 1 - Classificação hierárquica da declividade do relevo desenvolvida por Ross, 1994

\begin{tabular}{lcc}
\hline \multicolumn{1}{c}{ Up to 6\% } & Slope Classes \\
\hline Between 6\% and 12\% & Plan \\
Between 12\% and 20\% & Soft corrugated \\
Between 20\% and 30\% & Corrugated \\
Above 30\% & Strong corrugated \\
\hline
\end{tabular}

Source: ROSS, 1994

Geographic information on roads, rural communities and urban areas was acquired through data processing of the municipality's Municipal Sanitation Plan in shapefile format, and through visual analysis of the images available on Google Earth Pro.

\section{Results and discussion}

The Alto do Rio Doce Environmental Protection Area is vegetated in 22.3\%, with the remaining $77.7 \%$ representing human altered land (Figure 2), mostly occupied by agriculture and pastureland activity. The kappa coefficient was 0.715 , considered as good. Similar land proportions were found by Souza et al. (2014), in the Coqueiral EPA, in Minas Gerais (28\% vegetation), suggesting that the mild restrictions placed on native vegetation in that Protected Area (PA) limits the possibility of monitoring action and control of impacting agents. Often pressures to which vegetation is subject in PA, is the result of agricultural activities (MORAES; MELLO; TOPPA,2017). Those authors affirm that the Porto Ferreira State Park, in the state of São Paulo is also composed of a matrix of the agricultural land with isolated fragments of 
vegetation cover. That landscape closely mirrors the landscape in the Alto Rio Doce EPA, while pasture land predominates.

\section{Figure 2 - Proportions of vegetation and non-vegetated areas in the Alto Rio Doce Environmental Protection Area (EPA) in Minas Gerais}

Figura 2 - Proporções de vegetação e áreas não vegetadas na Área de Proteção Ambiental do Alto Rio Doce (EPA) em Minas Gerais

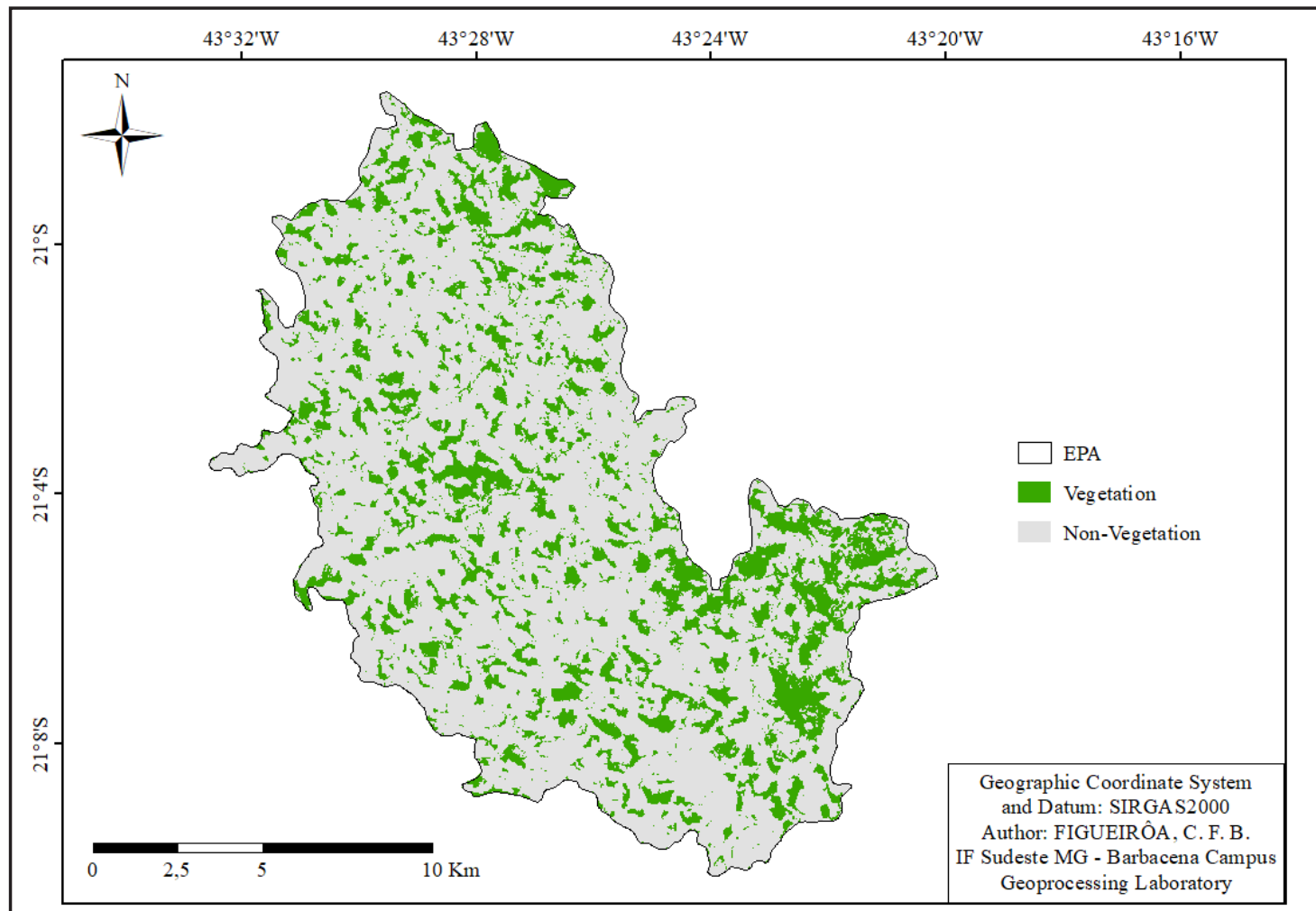

Source: Authors (2020)

The landscape matrix of the EPA (Figure 2) shows significant fragmentation, with an average size of 2.9 hectares. Souza et al. (2014) also found a large proportion of small fragments in the Coqueiral EPA, Minas Gerais, corroborating for the indication of the wide fragmentation in the state, as well as the study of forest fragments by Calegari et al. (2010). The negative effects of this scenario are known both for animals (BARBOSA et al., 2017) and for forest species (GROSS et al., 2018), which suggests a significant habitat fragility in the region.

The presence of roads within the EPA represents another threat to the ecological integrity of the site. Several roads cross the EPA, among them a paved state road, MG-132, which runs 21.5 $\mathrm{km}$ inside the area (Figure 3).

Despite their benefits, roads negatively impact the environment by fragmenting and destroying habitat (VAN DER REE et al., 2011), by increasing noise (FREIRE et al., 2011), by instigating behavioral changes in fauna, often leading to roadkill (HOLDEREGGER; DI GIULIO, 2010), by altering genetic pools (HOLDEREGGER; DI GIULIO, 2010; JACKSON; FAHRIG, 2011), by altering physical and chemical changes in the environment, and by the indirect suppression and introduction of species coincident with the increased human use of the area (VAN DER REE et al., 2011).

Although there is no legal restriction to the existence of roads within EPAs, the structure 
restricts the movement of wildlife. The results of the study by Andrade and Moura (2012) on a highway that cuts Biological Reserve in the state of Pernambuco, Brazil, shows that the road might acting like a barrier to the animal flow, once that was register of run over, temperature and sound effects has a potential influence on an urofauna deslocation. Negative impacts on the population of other animals, such as birds (BAGER; ROSA, 2012), bats (BERTHINUSSEN; ALTRINGHAM, 2012), large mammals (SWITALSKI; NELSON, 2011) and invertebrates (BEIROZ; ZAU; CASTRO, 2010) have also been reported in several regions intersected by roads, especially in Protected Areas.

Figure 3 - Roads, districts and rural communities present in the Environmental Protection Area (EPA) of the Alto Rio Doce in Minas Gerais

Figura 3 - Estradas, distritos e comunidades rurais presentes na Área de Proteção Ambiental (APA) do Alto Rio Doce em Minas Gerais

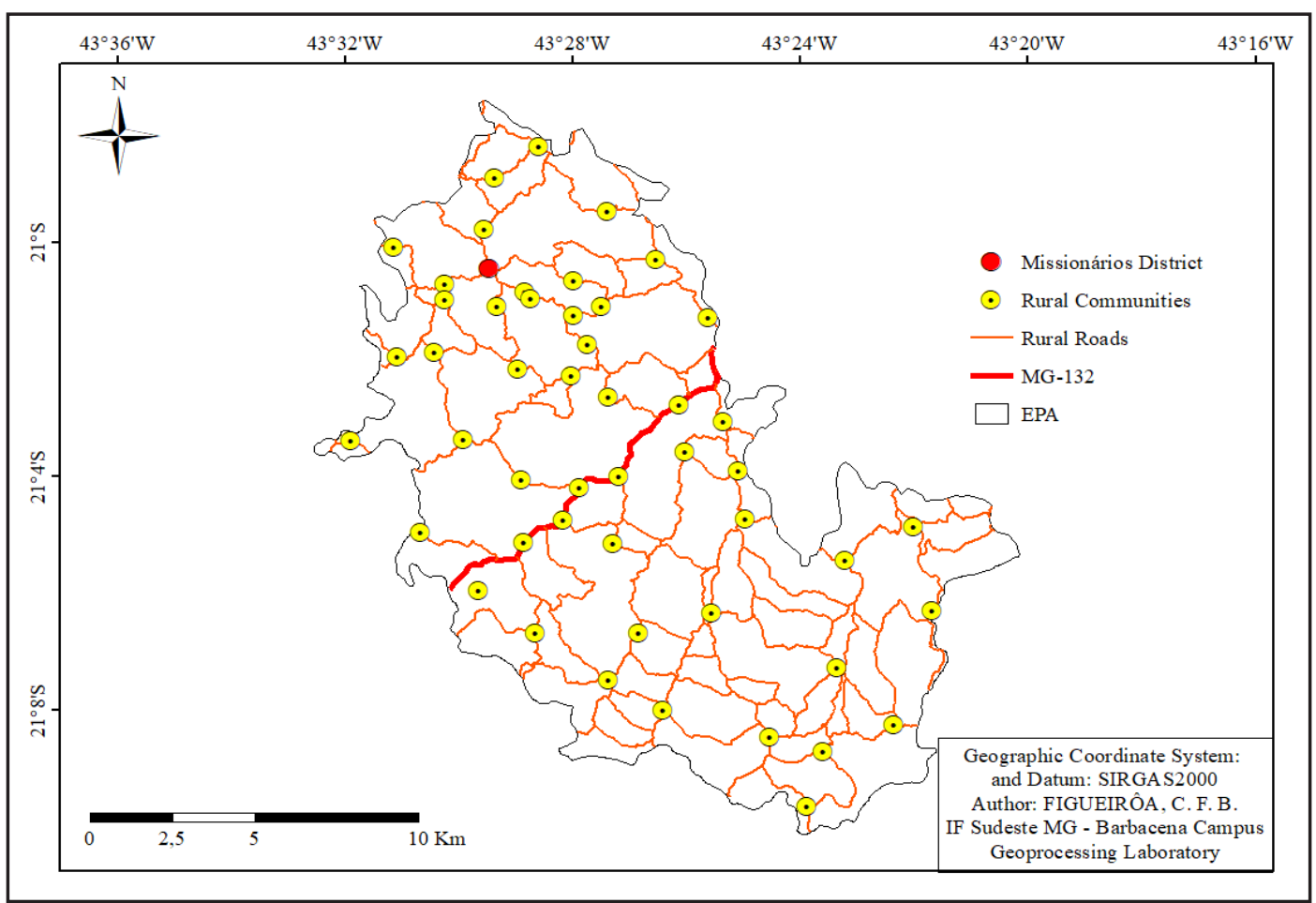

Font: Authors (2020)

The Alto do Rio Doce EPA contains $319.5 \mathrm{~km}$ of rural roads. Although the vehicular traffic is reduced on these unpaved roads, the very construction of these roads and their subsequent extension, results in negative impacts such as increased fragmentation within the EPA territory.

Within the EPA there is only one consolidated urban area, the District of Missionários, of the municipality of Alto Rio Doce, and 41 other small rural communities (Figure 3 ). The district represents less than $1 \%$ of the territory of the EPA, suggesting that much of the human-impacted area that exerts pressure on the vegetation represents agricultural activities. Another factor underscoring the pressure of agricultural activities is high fraction (27.3\%) it represents of the overall the Municipal Gross Domestic Product (GDP) (CIRINO; GONZÁLES, 2011), well above that of neighboring municipalities.

The topography of the area varies from mild to moderately hilly over most of the EPA, representing $89.2 \%$ (Figure 4). When any given transect is examined, there is an apparent direct relationship between slope and the amount of vegetation (Table 2), with intact vegetation 
often found on the steepest slopes. This common pattern stems from the historical difficulties associated with clearing or extracting timber from steep slopes, as well as the inability of agricultural machinery to operate in these areas (GRISA et al., 2015).

Figure 4 - Topographic slope of the Alto Rio Doce Environmental Protection Area (EPA) in Minas Gerais

Figura 4 - Inclinação topográfica da Área de Proteção Ambiental (APA) do Alto Rio Doce em Minas Gerais

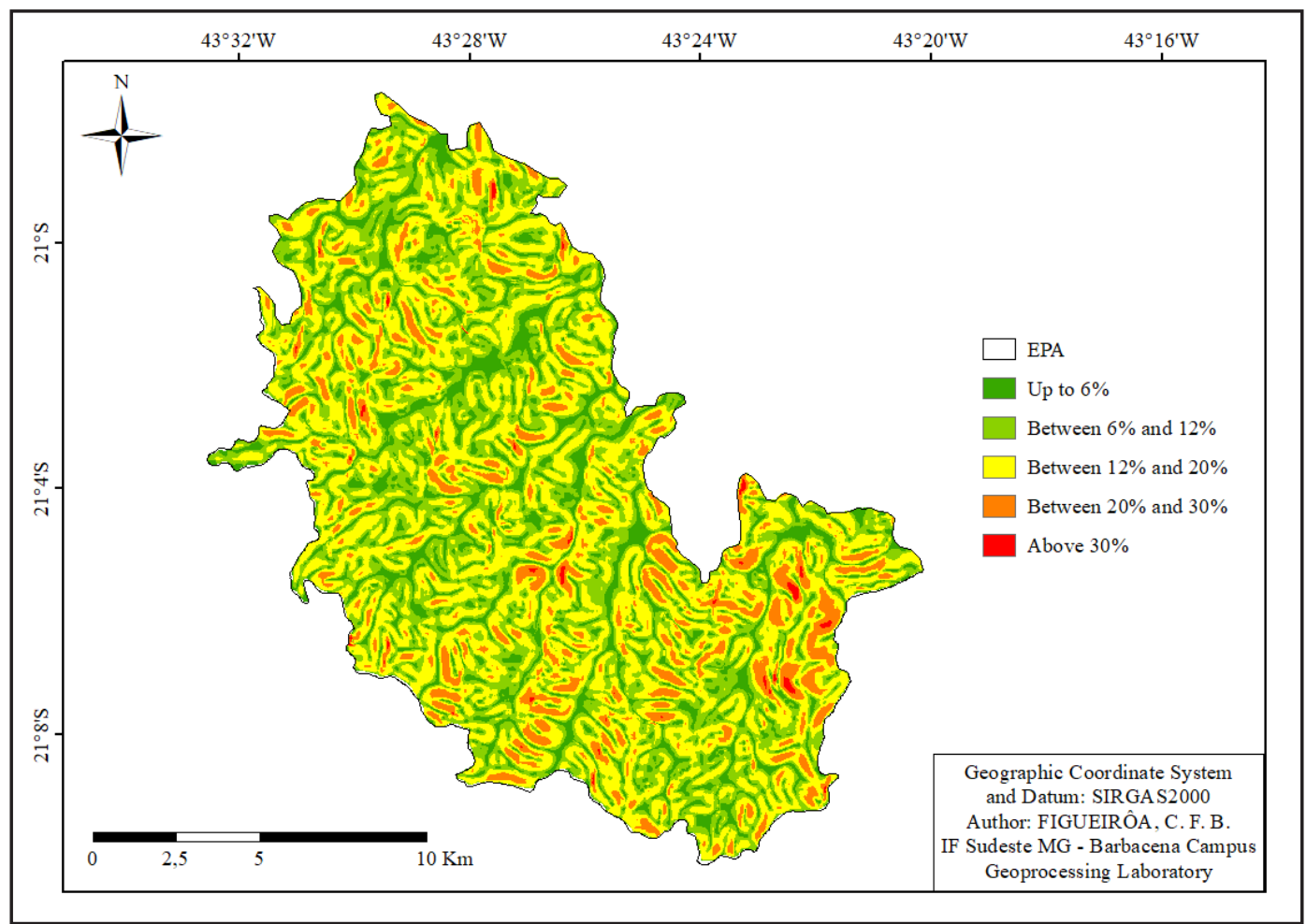

Font: Authors (2020)

Table 2 - Area with vegetation present by slope class in the Alto do Rio Doce Environmental Protection Area (EPA) in Minas Gerais

Tabela 2 - Área com vegetação presente nas classes de declividade na Área de Proteção Ambiental Alto Rio Doce (APA) em Minas Gerais

\begin{tabular}{lc}
\hline \multicolumn{1}{c}{ Slope Classes } & Vegetation Area $(\%)$ \\
\hline Up to 6\% & 14.64 \\
Between 6\% and 12\% & 32.41 \\
Between 12\% and 20\% & 42.11 \\
Between 20\% and 30\% & 10.51 \\
Above 30\% & 0.33 \\
\hline
\end{tabular}

Font: Authors (2020) 


\section{Conclusions}

Our results suggest that the Alto do Rio Doce Environmental Protection Area remains in a very fragile state reinforcing the need to implement a Management Plan predicated upon local dynamics. In spite of the low restriction of this category of Protected Area, an adequate Management Plan, which could appropriately direct the creation of a plan for recreational activities, such as trails and interpretive elements that promote environmental education, would increase its effectiveness and contribute to public awareness. Currently the public is generally unaware of the existence of the EPA, which impedes the effectiveness of conservation efforts.

In this study we highlight a high degree of fragmentation and human intervention, which should generate concern in the reader as the conservation of these remnants becomes essential for the preservation of the Atlantic Forest, a biome which has become since human occupation. The concept of the biodiversity hotspot was created to general public concern and galvanize action to area around the world of specific biological concern, and although there is no single recipe for conservation action, effective conservation action begins with local concern for local landscapes.

\section{Acknowledgment}

The authors thank the Instituto Federal do Sudeste de Minas Gerais for financial support for the english translation of this article, the James Bruce Bell biologist for the english revision and technical suggestions, and Dr. José Emílio Zanzirolani de Oliveira, Profa. Alcimara Auxiliadora Andrade de Paula, Tatiana Mara dos Santos Azevedo Grunewald and Tatiana dos Reis G. Ferreira for text revisions.

\section{References}

ALVARES, C. A.; STAPE, J. L.; SENTELHAS, P. C.; GONÇALVES, J. L. M.; SPAROVEK, G. Köppen's climate classification map for Brazil. Meteologische Zeitschrift, Berlim, v. 22,n. 6, p. 711-728, 2014.

ANDRADE, E. V. E.; MOURA, G. J. B. Proposta de manejo das rodovias da ReBio Saltinho para mitigação do impacto sobre anurofauna de solo. Revista Ibero-Americana de Ciências Ambientais, Aquidabã, v. 2, n. 2, p. 24-38, 2011.

BAGER, A.; ROSA, C.A. Impacto da rodovia BR-392 sobre comunidades de aves no extremo sul do Brasil. Revista Brasileira de Ornitologia, Rio Grande-RS, v. 20, n. 1, p. 30-39, 2012.

BARBOSA, K.V.C.; KNOGGE, C.; DEVELEY, P.F.; JENKINS, C.N.; UEZU, A. Use of small Atlantic Forest fragments by birds in Southeast Brazil. Perspectives in Ecology and Conservation, [s/l], v. 15, p. 42-46, 2017.

BEIROZ, W.; ZAÚ, A. S.; CASTRO JR, E. Impacto das Estradas na Distribuição de Besouros em um Fragmento de Mata Atlântica de Encosta no Parque Nacional da Tijuca, Rio de Janeiro, RJ. Entomo Brasilis, Vassouras-RJ, v. 3, n. 3, p. 64-68, 2010.

BERTHINUSSEN, A.; ALTRINGHAM, J. The effect of a major road on bat activity and diversity. Journal of Applied Ecology, [s/l], v. 49, n. 1, p. 82-89, 2012.

BUTCHART S. H. M.; WALPOLE, M.; COLLEN, B.; VAN STRIEN, A.; SCHARLEMANN, J. P. W.; ALMOND, R. E. A.; BAILLIE, J. E. M.; BOMHARD, B.; BROWN, C.; BRUNO, J.; CARPENTER, K. E.; CARR, G. M.; CHANSON, J.; CHENERY, A. M.; CSIRKE, J.; DAVIDSON, N. C.; DENTNER, 
F.; FOSTER, M.; GALLI, A.; GALLOWAY, J. N.; GENOVESI, P.; GREGORY, R. D.; HOCKINGS, M.; KAPOS, V.; LAMARQUE, J. F.; LAVARINGTON, F.; LOH, J.; MCGEOCH, M. A.; MCRAE, L.; MINASYAN, A.; MORCILLO, M. H.; OLDFIELD, T. E. E.; PAULY, D.; QUADER, S.; REVENGA, C.; SAUER, J. R.; SKOLNIK, B.; SPEAR, D.; STANWELL-SMITH, D.; STUART, S. N.; SYMES, A.; TIERNEY, M.; TYRRELL, T. D.; VIÉ, J. C.; WATSON, R. Global biodiversity: indicators of recent declines. Science, [s/1], v. 328, p. 1164-1168, 2010.

CALEGARI L.; MARTINS, S. V.; GLERIANI, J. M.; SILVA, E.; BUSATO, L. C. Análise da Dinâmica de Fragmentos Florestais no Município de Carandaí, MG, para fins de restauração florestal. Revista Árvore, Viçosa-MG, v. 34, n. 5, p. 871-880, 2010.

CIRINO, J.F.; GONZÁLEZ, A. M. G. O. A heterogeneidade do desenvolvimento econômico do estado de Minas Gerais. Revista de Ciências Humanas, Florianópolis-SC, v. 11, n. 1, p. 9-11, 2011.

FARR T. G.; ROSEN, P. A.; CARO, E.; CRIPPEN, R.; DUREN, R.; HENSLEY, S.; KOBRICK, M.; PALLER, M.; RODRIGUEZ, E.; ROTH, L.; SEAL, D.; SHAFFER, S.; SHIMADA, J.; UMLAND, J.; WERNER, M.; OSKIN, M.; BURBANK, D.; ALSDORF, D. The Shuttle Radar Topography Mission. Review of Geophysics, [s/1], v. 45, n. 2, p. 1-33, 2007.

FREIRE R. B.; MIRANDA, Z. A. I.; MORELLI, A. F. Impactos ambientais causados pela rodovia Arlindo Bettio (SP 613) no Parque Estadual do Morro do Diabo - SP. Tópos, Presidente PrudenteSP, v. 5, n. 2, p. 89-101, 2011.

FREITAS LIMA, E. A. C.; RANIERI, V. E. L. Land and use planning around protected areas: Case studies in four state parks in the Atlantic forest region of southeastern Brazil. Land Use Policy, [s/1],v.71, p. 453-458, 2018.

GRISA, K. T.; ROCHA, A. S.; BADE, M. R.; CUNHA, J. E. Mapeamento da Fragilidade Potencial: Estudo de Caso do Alto Curso da Bacia Hidrográfica do Rio Cotegipe - PR. Geografia em Questão, [s/1], v. 8, n. 1, p. 138-149, 2015.

GROSS A.; SILVA, A. C.; CRUZ, A. P.; KILCA, R. V.; NUNES, A. S.; DUARTE, E.; VEFAGO, M. B.; SANTOS, G. N.; LIMA, C. L.; SALAMI, B.; HIGUCHI, P. Fragmentation as a key driver of tree community dynamics in mixed subtropical evergreen forests in Southern Brazil. Forest Ecology and Management, [s/1], v. 411, p. 20-26, 2018.

HOLDEREGGER R.; DI GIULIO, M. The genetic effects of roads: a review of empirical evidence. Basic and Applied Ecology, [s/1], v. 11, n. 6, p. 522-531, 2010.

JACKSON, N. D.; FAHRIG L. Relative effects of road mortality and decreased connectivity on population genetic diversity. Biological Conservation, [s/l], v. 144, n. 12, p. 3143-3148, 2011.

KNÖRR, U. C.; GOTTSBERGER, G. Differences in seed rain composition in small and large fragments in the northeast Brazilian Atlantic Forest. Plant Biology, [s/l], v. 14, p. 811-819, 2012.

MARTIN, A.; COOLSAET, B.; CORBERA, E.; DAWSON, N. M.; FRASER, J. A.; LEHMANN, I.; RODRIGUEZ. Justice and conservation: the need to incorporate recognition. Biological Conservation, [s/l], v. 197, p. 254-261, 2016.

MASSA, E.M.; ROSS, J. L. S. Aplicação de um modelo de fragilidade ambiental relevo-solo na Serra da Cantareira, bacia do Córrego do Bispo, São Paulo-SP. Revista do Departamento de Geografia - USP, São Paulo-SP, v. 24, p. 57-79, 2012.

MORAES, M.C.P; MELLO, K; TOPPA, R.H. Protected areas and agricultural expansion: Biodiversity conservation versus economic growth in the Southeast of Brazil. Journal of Environmental Management, v. 188, p. 73-84, 2017

MURADIAN, R.; CORBERA, E.; PASCUAL, U.; KOSOY, N. Reconciling theory and practice: An alternative conceptual framework for understanding payments for environmental services. 
Ecological Economics, [s/l], v. 69, n. 6, p. 1202-1208, 2010.

OLIVEIRA, V. S.; LIMA, G. S.; OLIVEIRA, L. S.; BRINATI, A. Diagnóstico e análise das áreas de proteção ambiental em Minas Gerais. In: LIMA, G. S.; BONTEMPO, G.; ALMEIDA, M.; GONÇALVES, W. (Orgs.). Gestão, pesquisa e conservação em áreas protegidas. Viçosa, MG: UFV; 2012. p. 101-118.

RITTL, T.; COOPER, M.; HECK, R. J.; BALLESTER, M. V. R.. Object-Based Method Outperforms Per-Pixel Method for Land Cover Classification in a Protected Area of the Brazilian Atlantic Rainforest Region. Pedosphere, v. 23, n. 3, p. 290-297, 2013.

ROSS, J. L. S. Análise Empírica da Fragilidade dos Ambientes Naturais e Antropizados. Revista do Departamento de Geografia - USP, São Paulo-SP, v. 8, p. 63-74, 1994.

SALVIO, G. M. M.; FONTES, M. A. L.; SILVEIRA-JÚNIOR, W. J.; SILVA, H. A. Conservation areas, poverty and social inequality: an evaluation using socioeconomic indicators in Minas Gerais, Brazil. Revista Cerne, Lavras-MG, v. 22, n. 2, p. 145-150, 2016.

SALVIO, G.M.M. Áreas Naturais Protegidas e Indicadores Socioeconômicos: o desafio da conservação da natureza. Jundiaí: Paco Editorial, 2017. 216 p.

SOS MATA ATLÂnTICA. Atlas dos remanescentes florestais da Mata Atlântica - Período 2016-2017 - Relatório Técnico. 2018. Avaiable in: <http://www.sosma.org.br/projeto/atlas-damata-atlantica/dados-mais-recentes/>. Access in: 29 mai. 2018.

SOUZA, C. G.; ZANEllA, L.; BORÉM, R. A. T.; CARVAlHO, L. M. T.; ALVES, H. M. R.; VOLPATO, M. M. L. Análise da fragmentação florestal da Área de Proteção Ambiental Coqueiral, Coqueiral - MG. Ciência Florestal, Santa Maria-RS, v. 24, n. 3, p. 631-644, 2014.

SWITALSKI, T. A.; NELSON, C. R. Efficacy of road removal for restoring wildlife habitat: Black bear in the Northern Rocky Mountains, USA. Biological Conservation, [s/l], v. 144, n. 11, p. 2666-2673, 2011.

VAN DER REE, R.; JAEGER, J. A. G.; VAN DER GRIFT, E. A.; CLAVENGER, A. P. Effects of roads and traffic on wildlife populations and landscape function: road ecology is moving towards larger scales. Ecology and Society, [s/1], 2011; v. 16, n. 1, art. 48. [online] URL: http://www. ecologyandsociety.org/vol16/iss1/art48/ 
